\title{
Written Communication
}

\section{Gig expectations: Literacy practices, events and texts in the gig economy}

\begin{tabular}{|c|c|}
\hline Journal: & Written Communication \\
\hline Manuscript ID & WC-20-0117.R3 \\
\hline Manuscript Type: & Original Article \\
\hline Keywords: & $\begin{array}{l}\text { Workplace Writing and Literacy, Genre Theory, Multiliteracies, Digital } \\
\text { Writing, Accessibility, Identity }\end{array}$ \\
\hline Abstract: & $\begin{array}{l}\text { This article explores the writing and reading requirements of the literacy } \\
\text { practices, events and texts characteristic of work mediated by the online } \\
\text { labor platforms of the gig economy, such as Airtasker and Freelancer, } \\
\text { which bring together people needing a job done with those willing to do } \\
\text { it. These emerging platform-based discourse communities and their } \\
\text { associated literacies are a new domain of social activity. Based on an } \\
\text { examination of seven gig economy platforms the article examines the } \\
\text { core literacy event in the gig economy, the posting and bidding for tasks, } \\
\text { together with the texts that enhance and support this process. While } \\
\text { some tasks require written texts as the outcome or product, all tasks } \\
\text { involve the creation of some form of written text as part of doing the } \\
\text { work. These texts are both interactional and interpersonal. As well as } \\
\text { being a part of negotiating and then getting a task done, they relate to } \\
\text { the complexities of building the identities, knowledge and relationships } \\
\text { required of those working in a virtual workspace rather than a traditional } \\
\text { workplace (Farrell, 2006, 2009). While most of these texts reflect } \\
\text { familiar text types, the core text cycle is argued to be an "emergent" } \\
\text { genre (Miller, 2017). Implications for education are presented. }\end{array}$ \\
\hline
\end{tabular}

\section{SCHOLARONE Manuscripts}




\title{
Gig expectations: Literacy practices, events and texts in the gig economy
}

\begin{abstract}
This article explores the writing and reading requirements of the literacy practices, events and texts characteristic of work mediated by the online labor platforms of the gig economy, such as Airtasker and Freelancer, which bring together people needing a job done with those willing to do it. These emerging platform-based discourse communities and their associated literacies are a new domain of social activity. Based on an examination of seven gig economy platforms, the present article examines the core literacy event in the gig economy, the posting and bidding for tasks, together with the texts that enhance and support this process. While some tasks require written texts as the outcome or product, all tasks involve the creation of some form of written text as part of doing the work. These texts are both interactional and interpersonal. As well as being a part of negotiating and then getting a task done, they relate to the complexities of building the identities, knowledge and relationships required of those working in a virtual workspace rather than a traditional workplace (Farrell, 2006, 2009). While most of these texts reflect familiar text types, the core text cycle is argued to be an "emergent" genre (Miller, 2017). Implications for education are presented.
\end{abstract}

Keywords: work-related literacy, Industry 4.0, digital literacy, Literacy 4.0, new media genres

\section{Introduction}

Government responses to the global COVID-19 pandemic have particularly affected members of the "precariat" (Standing, 2011), workers in employment sectors such as services and hospitality who already have low job security. One group of workers with especially low job security are those working in the gig economy, who bid for and often complete work via online labor platforms. These 
"platform workers" (McDonald et al., 2019) are likely to be strongly affected by pandemic lockdowns and their aftermath. Yet, as the Fourth Industrial Revolution continues to transform industries, types of work, and ways of working (Schwab, 2016), many workers are being forced to find new and innovative ways to promote themselves, build relationships and get work done via these platforms.

The transformation of industries in Industry 4.0 is the result of the ubiquitous use of digital data in all aspects of product development and distribution. At one end of the scale, the identification and application of patterns in data allows artificially intelligent processes to be applied in "smart" factories. At the other end of the scale, digital online labor platforms allow individual workers to respond to opportunities to carry out short term tasks (or "gigs") in rapid response to customer needs in the "gig economy". This article reports on research that is part of a broader project examining the literacy practices required for work in the gig economy, in smart factories, and in other work contexts marked by high technological convergence (Farrell, Newman \& Corbel, 2020). Our focus is on what we call Literacy 4.0 , the literacy practices that are characteristic of the emerging domain of digital workspaces (Farrell, 2006, 2009) of Industry 4.0. These workspaces are a central feature of the Fourth Industrial Revolution and of the data-driven artificial intelligence embedded in products and processes known as the Internet of Things (Wisskirchen, 2017).

Work and life are now mediated by increasingly diverse kinds of digital platforms, with the result that the word platform can be tricky to define. The word has been most commonly used in reference to social media platforms such as Facebook, Instagram, TikTok, and Linkedln, but a platform may be any digitally coded infrastructure that enables multiple users or groups, often performing different roles, to both input and receive information or data ("content") via a user interface. In this way, a digital platform can provide a space where social activity, including work, happens. Crucially, however, it is in the design of the specific kind of platform that the scope and types of interaction among users are decided and defined, particularly in the user interface, where content is displayed to the user(s) and options for inhabiting specific roles and inputting content are 
made available. As Srnicek (2017) reminds us, platforms are a kind of business model that is becoming ever more central to the global economy and though they may provide the infrastructure and intermediation between different groups, their primary function is the collection, storing and management of user-generated data.

The research reported here focuses specifically on the literacy practices of Industry 4.0 as they are manifested in the online collaborative labor platforms associated with the gig (also known as the "sharing" or "on-demand") economy (State of Victoria, 2020). We focus on platforms that have been specifically designed to enable communication between short term, on-demand workers and customers - platforms such as Airtasker, Uber and Freelancer. These platforms all have in common a mechanism for building and maintaining a community of buyers and sellers of services. Customers are typically individuals as well as small to medium businesses. Tasks are those which are likely to be beyond the scope of a customer's ability or core business. These can be anything from simple home repairs to preparing a report or designing a logo, depending on the focus of the platform. Importantly, the workers who use these platforms are considered to be self-employed, rather than employed by the companies who manage the platforms (and collect and store usergenerated data), meaning that work insurance, superannuation and overhead costs such as maintenance of equipment and facilities must be borne by the worker (McDonald 2019; Srnicek 2017).

As a recent inquiry into the status of this on-demand workforce has observed, the practice of workers being sourced on an as-needed basis is not new but "the emergence of digital platforms that source, sort, organise or deploy workers presents a shift in the efficiency and accessibility of ondemand work over the last decade" (State of Victoria, 2020, p.10). It is these online labor platforms that enable gig work, facilitating, rapidly and on a large scale, the sourcing and matching of workers to particular work tasks. We argue that these platforms not only enable gig work, but in many ways define it, as the digital communication infrastructure that they provide sets the parameters for the 
literacy practices that animate work in the gig economy. We ask, what are the literacy requirements, the "gig expectations", of work in this new social domain? What are the roles of writing and reading in the literacy practices that characterise these new ways of working? In short, what are the literacy practices that support work in Industry 4.0 ?

The core "literacy event" (Barton \& Hamilton, 1999) in the gig economy is a collaborative process of posting tasks to be done and bidding to carry them out. This core event is both instrumental and social in that it involves mechanisms for building relationships, identity and knowledge to ensure success within a platform community. In the absence of physical contact, this work is now wholly dependent on texts. We adopt a social view of literacy in which "...literacy is best understood as a set of social practices; these are observable in events which are mediated by written texts" (Barton \& Hamilton, 1999, p. 9). This article focuses on the literacy practices, events and texts that accompany work in the gig economy because this will provide insights into the nature of gig work and the communicative and literacy demands placed on workers in Industry 4.0. These insights, in turn, will enable more critical interrogation of issues relating to equity of access to gig economy work for individuals with diverse experiences of literacy education, and indeed to the quality of literacy support offered to workers by the platforms themselves.

We begin with a description of the gig economy and outline the social view of literacy we espouse. We proceed with a review of previous research and an outline of our approach and methodology. We then present the findings in the form of an examination of the core literacy event on online labor platforms, followed by a discussion of the texts and genres associated with the literacy event and the implications for educators.

\section{From workplaces to workspaces}

As an employment system, the gig economy has three main features (Richardson, 2015; Martin, 2016). The first is the use of online labor platforms to bring together people who need a task done 
with others who are willing to do it. The second is the distinctive employment relationship between platforms, customers and workers. Workers are treated as stand-alone entities fully responsible for all aspects of their own working lives. While this is often presented in public debate as an empowering form of self-employment, the potentially exploitative nature of this form of employment contract for individuals, and the financial benefits of outsourcing that accrue to employers and firms, is extensively argued as well (Avis, 2018; Aloisi, 2016, McDonald et al., 2020). The third distinguishing feature of the gig economy is the distribution of platform roles. There is a vast difference in size between the small core group of contracted employees which develops and manages the platform and the very large number of workers who carry out the tasks. These arrangements are supported by industry (Australian Industry Group, 2016; Deloitte Development, 2017) as well as being the target of critique (Avis, 2018; Chalmers \& Quigley, 2017).

In one sense this pattern of work is not new. It draws upon those whose work has always had a freelance aspect, such as musicians (the source of the term gig) and some professionals. What is new, however, is that it may now attract those displaced by industry disruption, such as in manufacturing, where work has traditionally been relatively secure and has included benefits such as sick and annual leave (Dean \& Spoehr, 2018). The conditions of the gig economy may well prefigure the increasingly precarious conditions of other sectors of the workforce, especially in service industries dominated by low paid women and migrant workers, like hospitality, childcare, and aged care, but also in traditionally secure sectors dominated by highly regulated trades. The increasing precariousness, or "precarity" (Sutherland, et. al. 2020), of nearly all work has been brought into stark relief by the COVID-19 global pandemic, as a result of which the gig workforce is likely to grow in both gross employment numbers and in the range of employment sectors affected.

The literacy requirements of work have changed as well (Farrell, 2001), not just for professional writers (Kirschenbaum, 2016) but for all professionals, and indeed, all workers (Brandt, 2015). The "informating" (Zuboff, 1988) of work processes, whereby actions are converted into information (data) which makes them visible and measurable, is now so ubiquitous that not just 
paper but screens themselves are being obscured with the emergence of the Internet of Things, in which artificial intelligence is applied to vast amounts of data to produce industrial processes and products based on newly appropriated areas of human behaviour in an emerging "surveillance capitalism" (Zuboff, 2019).

A further influence on the literacy practices of workspaces, in addition to changes in work, are the changes in texts themselves. The long-standing interdependence of reading, writing, speaking and listening (Barton \& Hamilton, 1999 p. 9) is expressed in new ways in texts that are no longer clearly paper- or screen-based, but, rather, routinely multimedia in character (de Pourbaix, 1999; Cope \& Kalantzis, 2000; Thorne, 2013). It is now common for texts to be collaboratively created, and the number of text creators who may work together to produce a text has risen exponentially over the past two decades. There is a "massification" of writing (Brandt, 2015) and arguably a re-massification of reading thanks in part to the ubiquity of social media. These textual changes are reflected in the literacy practices of the gig economy as well.

Although there has been a great deal of debate surrounding digital literacies in general (see Thorne (2013) for an overview), and some general commentaries on literacy in Industry 4.0 (Coldwell-Neilson \& Cooper, 2019; Farrell, Newman \& Corbel, 2020; Fehring, 2020), the specific literacy needs of those working in the gig economy are only now starting to be addressed. Carrigan (2018) refers to "platform literacy", which focuses on knowledge about the platform rather than on the moment-by-moment textual production within the workspaces which these platforms provide. Sutherland, et al. (2020) refer to "gig literacies", by which they mean the "creative literacies" (p. 458) with which workers manage the precarity of gig work. However, there remains a need to understand the social and textual practices required for effective participation in the gig economy and how policymakers, educators, careers advisors and support staff can help prepare students and workers to engage with it. 
Our preference for a social view of literacy is based on the notion of literacy as part of a social "ecology" (Barton, 1994). Social approaches to the study of literacy typically focus on literacy as regular, text-mediated literacy events that are a part of social literacy practices involving written texts, shared among people in particular settings and communities (Street, 1993; Graddol, Maybin \& Stierer, 1994; Hamilton, Barton \& Ivanic, 1994; Baynham, 1995; Hawkins, 2013). A social view of literacy is particularly relevant in light of the focus on community formation espoused by most online labor platforms themselves. As we have argued elsewhere:

While it is certainly the case that new forms of literacy change the ways that working knowledges and working identities are understood and produced ... the distinctive demand that Industry 4.0 makes on literacy practices is the unrelenting attention that needs to be given to establishing, maintaining and repairing relationships. (Farrell, Newman \& Corbel, 2020, p. 5)

Most research on literacy in online settings has focused on changing literacy practices in educational and social settings (Pigg et al., 2014; Jaworski, 2015; Messina-Dahlberg \& Bagga-Gupta, 2016). Less research has addressed changing literacy practices in new online professional and vocational settings (though see Collin, 2011; Ducheneaut \& Bellotti, 2010; Sutherland et al., 2020). Although recent studies have examined the cultural and legal aspects of labour practices in the gig economy (Aloisi, 2016; Healy, Nicholson \& Pekarek, 2017), and there is some work on the "shared" economy (Richardson, 2015; Martin, 2016), there is none to date that examines the literacy practices, events and texts of the online labor platforms of the gig economy.

The workplace has long been studied as a setting for literacy practices (Gee, Lankshear \& Hull, 1996; Farrell, 2006, Hull \& Zacher, 2007). A particular focus has been on the effect of changes in reading and writing requirements that have accompanied changes in work practices as workplaces have become more automated and "textualised" (Zuboff, 1988; see also Baynham \& Prinsloo, 2009; Farrell \& Fenwick, 2007; Farrell, 2009; Brandt, 2005, 2009, 2015). Some early writers within the field 
of information science also addressed some of the non-technical aspects of emerging online textual practices (Barrett, 1993; Brown \& Duguid, 2000). An abiding concern within workplace literacy studies has always been with the relationship between workplace changes, literacy, and the formation and framing of individual worker identity (Turkle, 1997; Sennett, 1998; Farrell, 2000, 2006).

The kinds of literacy practices examined in different workplaces have changed over time, but all have increasingly involved writing. Even formerly exclusively physical work now involves a crucial textual element (Zuboff, 1998; Farrell, 2006) which is frequently highly restrictive and externally determined. While this may have benefits for the firm or supply chain in the form of "adaptive case management" (Fisher, 2016), it also causes problems, for example, where reports are framed by restrictive requirements such as templates (Sellen \& Harper, 2002; Brandt, 2016; Karlsson \& Nikolaidou, 2015). At the same time, knowledge workers in informated organisations are increasingly shaping them to their own needs, for example, using "email as habitat" (Ducheneaut \& Bellotti, 2001).

Textual and social practices come together in texts as genres, which both shape and are shaped by literacy practices. We draw upon the rhetorically-oriented perspective of genre which is captured in Miller's $(1984,2014)$ notion of "genre as social action" to contribute to our account of the ways that genres are emerging from the specific workspaces generated by the platforms of the gig economy. Bawarshi and Reiff (2010) conclude their overview of studies of electronic genres in workplace contexts with a call for "further studies (...) to examine the process of importing existing genres and genre systems, improvising around them, and learning to take advantage of new and emergent genres"(p. 170). This article is intended to contribute to that investigation. It builds on Brandt's work on literacy in the knowledge economy $(2005,2009,2015)$, which examined the changing writing practices of workers over a twenty-year period. Her work takes us up to the beginning of the new vocational workspaces and working literacies of Industry 4.0. Her subjects still 
worked within companies and called upon them internally for support. Nowadays, as companies shed workers, many people like those Brandt studied are now left to fend for themselves in the gig economy. The textual requirements of those now working online and on their own in the workspaces of the gig economy are the focus of this article.

\section{Method}

Previous methodologies of research into online literacy practices have involved ethnography (Garcia et al., 2009), "netnography" (Kozinets, 2009; Sindhwani \& Ahuja, 2014) and discourse analysis (see Collin, 2011, for a discourse analysis of a popular guide to composing career portfolios). Our focus in this article is on how key texts shape and are shaped by their associated literacy events and practices. To achieve this aim we examined the publicly-available texts generated by the platforms' participants themselves, based on Template Analysis (King, 2012). As explained below, the texts were examined for patterns of commonality in the actions carried out by participants in the core gig work literacy event. On this basis, three categories of action and their associated texts were named. Each of the data texts were subsequently identified as being of a text type and in a text category, as shown in the Appendix.

The data were gathered from a desktop audit of the texts generated within a group of online labor platforms. Platforms and texts were selected for their range of text types and analysed using, as far as possible, their own terminology. The audit was framed by a literature review of vocational education and literacy journals and government and business reports based on key terms such as gig economy, sharing economy, microwork, microtasking, and digital labour. Platforms encountered in the literature review were examined for examples of the types of texts that were involved in negotiating and carrying out a task as well as the texts that were produced by platform workers as outcomes of a task. The examination involved visiting the platforms' home pages and clicking through the pages available to a visitor. Links from each platform's home page were cross-checked for content coverage against the site map found at the bottom of most home pages. 
From the twenty platforms examined, seven were chosen as representing a range of complexity across two dimensions - the textual outcomes produced by participants and the knowledge and skills involved in their production. These inputs and outputs are summarised in Table 1 . The phrases in brackets indicate the kinds of tasks that broadly exemplify the complexity involved.

Table 1

The complexity of platform textual outcomes

High

SkillShare

(Vocational

teaching

resources)

$\begin{array}{ll}\text { Scripted } & \text { 99designs } \\ \text { (Marketing } & \text { (Graphic } \\ \text { texts) } & \text { design) }\end{array}$

Freelancer

(A wide range of

Complexity

of textual

products

Airtasker CrowdFlower/Appen

(Local, (Reading tasks

mainly low requiring educated

skilled generalists)

physical

tasks)

Low

\section{Complexity of knowledge and skill required to produce the} products

Low

High

As with all gig tasks, those that involve writing as an outcome increase in complexity from the lower left to the upper right of the table. What the seven selected platforms also have in common is the use of writing to bring together buyers and sellers of a practical service or services, more of which are written texts as we move further to the top right. This difference in complexity 
aligns broadly with the differences between "microtasks" (Rolandsson et al., 2020) and "macrotasks" (Gegenhuber \& Schussler, 2020). This sample of seven platforms thus represents a range of complexity in terms of the literacy required in the task of creating written texts as a work product. In Table 1 the texts produced on the seven platforms are arranged according to their increasingly complex writing requirements. Airtasker focuses on everyday tasks, which have the lowest apparent requirements for writing. Freelancer offers more complex tasks and more text-oriented tasks than Airtasker, being aimed at a general and increasingly specialised audience of small businesses as well as individuals. CrowdFlower/Appen focuses on the relationship between humans and Artificial Intelligence, with a focus on reading rather than writing tasks which require reasonably educated generalists as workers. Local Motors focuses on generating ideas for new manufacturing and taking them to development, with an assumed reading and writing component. 99designs focuses on the existing (visual) literacy skills of its community. It is similar to Freelancer but more design focused. It is also similar to Scripted, but for graphic instead of written texts. Scripted is the most alphanumeric, print-oriented platform: print-based texts are its product as well as being part of the task process. Skillshare offers training in skills. This requires the preparation, delivery and promotion of multimedia texts. Crucially, whatever the nature of the textual products, the process involved in their production on the platform always involves writing. Our attention was drawn, however, to the consistency across this range in terms of these writing demands - the gig expectations - involved in negotiating as well as producing work. As a result, our research came to focus on the literacy practices involved in negotiating work of various kinds via these platforms, rather than on the textual demands of the work tasks themselves.

One of the authors joined each of the seven selected platforms as a member, which provided access to more of the texts involved in the online labor processes than was available on their public web pages. There was no active participation by the researcher in any of the platform communities, though there was significant engagement with the platform infrastructure and content, such as a prospective gig worker may encounter. The text selection was restricted to freely 
available textual material on the platform, with no direct contact with individual community members. While lack of such contact may have precluded direct participant observation in community activities, it nonetheless provided enough data for this initial framing of gig work literacy events. The author was (and remains) a legitimate but inactive member of the seven platform communities.

To identify patterns and make comparisons, a second examination of the seven selected platforms was undertaken, based on a standardised template which used the five headings below to focus on details of the platform, how it operates, the roles of its participants and the textual resources available to support them. These topics were chosen based on the issues raised in the literature review and the impressions gained during the initial visits to the platforms. The completed templates provided notes on each platform under the following headings:

1. The company: Reason for choosing this company, Tagline, Point of difference, Purpose/Beliefs/Values, Statistics

2. How it works: Joining, Participating, Projects, Contests

3. People: Team, Customers, Workers, Other

4. Resources: Blog, Guides, Experts, Other, Literacy tasks

5. Literacy audit: Tasks, Texts, Types, Links/Ligatures/Typology

In addition to the completed templates, actual texts were collected from the platforms. Of the many pages and texts encountered, 28 were selected for further examination based on their range, content and relevance to the breadth of the study's goal. These texts made specific reference to existing text types, such as blogs or position descriptions, or to aspects of literacy events, like engaging with customers. The collection of 28 texts comprised: job descriptions (8), blog entries (6), job advertisements (2), guides (2), media reports (2), task instructions (1), task descriptions (1), media releases (1), application forms (1), FAQ (1), academic journal articles (1), resumes (1), quizzes 
(1). The number of overall occurrences of these text types within the selected platforms was not recorded. Details of these 28 documents appear in the Appendix.

Where the chosen texts comprised long pages of items, such as blogs, the first page was saved, and the items on that page were viewed. Texts appearing as complete entities, such as position descriptions, were saved in full. The texts ranged in size and scope from a few lines to an academic journal article. The period of data collection, interpretation, review, and analysis ranged from 2017 to 2020 .

\section{Findings}

A literacy event is a culturally recognised activity that involves literacy (Barton \& Hamilton, 1999). The activities within most literacy events involve participants, actions and texts. This section presents the findings relating to the participants, actions and text types of what we call a gig work literacy event. In setting out the findings our focus is on identifying commonalities across the platforms that would provide a starting point for educators and researchers to engage further with literacy events in the gig economy.

All platforms have three participant roles which we have called Workers, Customers and Team Members, based on the labels used by the platforms themselves. The actual labels vary according to the platforms' own self-images as captured in their branding, reflecting the platforms' role in constructing the participants' identities, and the Workers' identities in particular. These are shown in Table 2.

Table 2

Names of participants on the online labor platforms

\begin{tabular}{|l|l|l|l|}
\hline Platform & Worker & Customer & Team Member \\
\hline Airtasker & Tasker & Poster & Team Member \\
\hline
\end{tabular}




\begin{tabular}{|l|l|l|l|}
\hline CrowdFlower/Appen & Contributor & Customer & Team Member \\
\hline Freelancer & Freelancer & Employer & Team Member \\
\hline Local Motors & Thinker, Tinkerer, Solver & Customer & Employee \\
\hline Scripted & Writer & Customer & Team Member \\
\hline 99designs & Designer & Customer & Team Member \\
\hline SkillShare & Teacher & Student & Team Member \\
\hline
\end{tabular}

Becoming a member of a platform community involves registering as a worker or as a customer. Registration is usually simple, though it may require additional actions such as taking a proficiency quiz on a platform such as Scripted, which focuses on specialised written texts. Potential workers describe themselves in as much detail as they wish. They may be able to attach samples of their work (99Designs). Such creation and curation of a personal brand is similar to a career portfolio, "... an increasingly common, yet under-examined feature of employment scenes in advanced capitalist economies" (Collin, 2011, p. 615). Unlike career portfolios, these profiles, like the platforms themselves, focus more on personal qualities than formal credentials. Potential customers begin by describing their need and may be guided through this process with a template (Freelancer). The third group of platform participants, after Workers and Customers, is Team Members. Unlike the workers, who are freelance, these are contracted employees of the platform in technical and customer service roles. Also unlike the workers, they are often depicted in the platform website imagery as working co-located in attractive, well-equipped offices. The team members still appear to inhabit physical workplaces, while the workers inhabit digital workspaces. Of course, workers may be physically located in a range of physical 'places' - homes, coffee shops, co-working spaces - but it is the digital space that is shaped by the platform infrastructure where work actually gets done and professional communities are built and maintained. 
Some platforms emphasise the notion of community as central to membership and it is through literate practice that participation in the communities is made possible. Airtasker members, for example, are encouraged to "hang out" on the platform between gigs. Hanging out involves making use of the various textual and communication resources on the platform. Although platform participants are all considered community members, and there is a cooperative tone to much of the platform content, there remains a fundamental tension between cooperation and competition between workers who need to bid against each other to get a gig.

The four key writing activities that constitute the literacy event of negotiating a gig are posting a task, making a bid, creating and maintaining a profile, and posting a review. These interrelated activities, and their corresponding text types - post, bid, profile, review - are often explicitly outlined as part of the requirements for participating in online labour platforms. Most commonly, the customer or client is involved in writing a post or a review of a worker, while the worker is involved in writing a bid, writing and continually updating a profile, and also potentially writing a review of the customer. Reading in various forms is also required, as the worker must browse tasks posted by customers, search key words, and review their own (and possibly others') profiles as they update them, while the customer must read through bids, profiles and reviews related to individual workers whom they may choose to hire. Other forms of literacy may also be called upon when engaging in the platforms. ${ }^{1}$ However, the central focus of the literacy event through which a gig is negotiated is on the written production of two core texts, the post and the bid (or offer). For the worker, the articulation of these gig expectations can be seen in Figure 1, a page from the Airtasker website that explains to potential workers "How to start earning" 2 This page is accessible via a link in the main navigation bar labelled "Become a Tasker", clearly indicating that these are the steps involved for attaining work in the gig economy via this platform. The content in Figure 1 is summarised in Table 3, highlighting in bold the four main actions and text types of the gig work literacy event. 
Figure 1

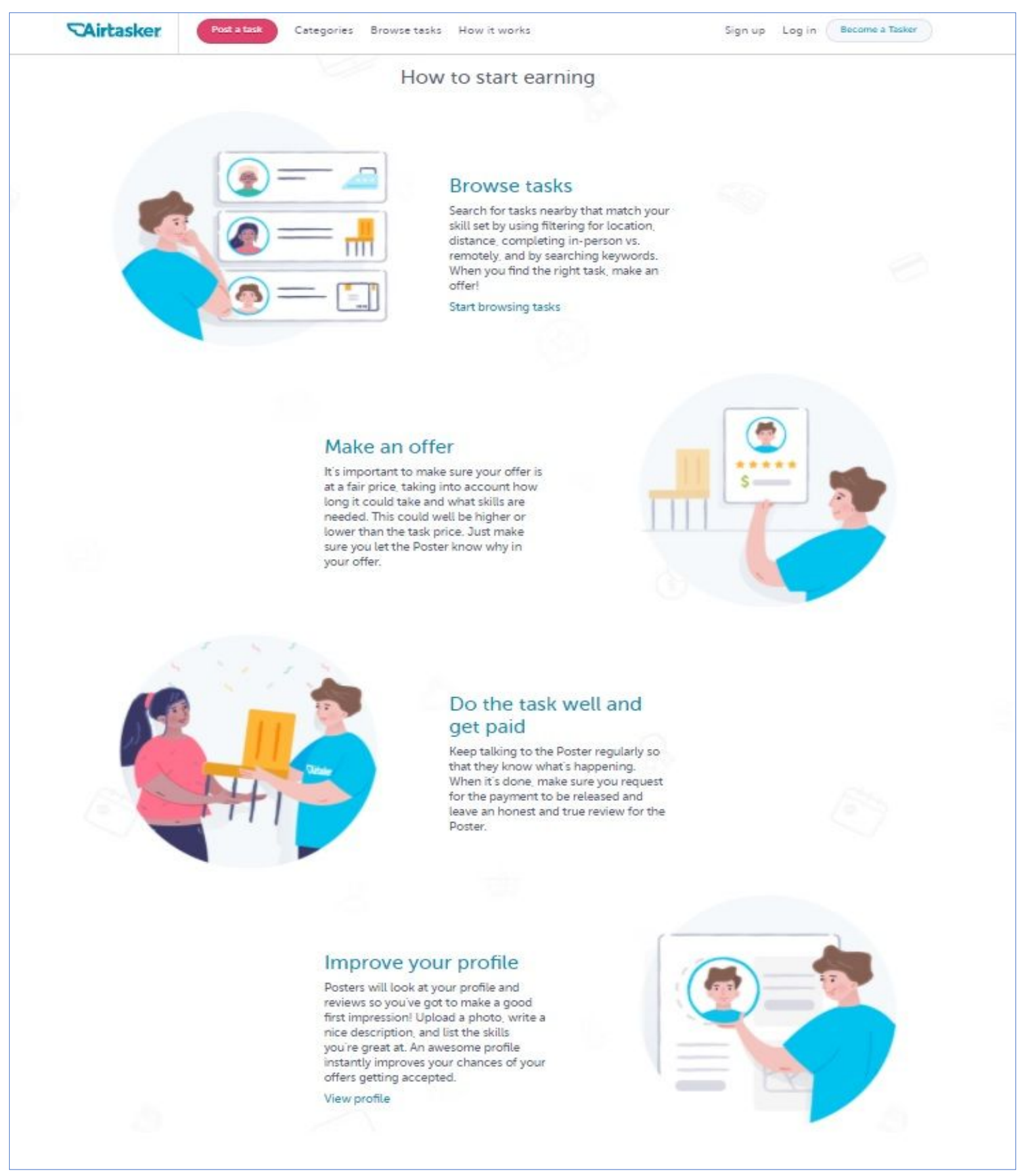

Table 3

Worker actions and text types in a gig work literacy event

\begin{tabular}{|l|l|l|l|}
\hline \multicolumn{4}{|c|}{ How to start earning } \\
\hline Browse tasks & Make an offer & $\begin{array}{l}\text { Do the task well and } \\
\text { get paid }\end{array}$ & Improve your profile \\
\hline
\end{tabular}




\begin{tabular}{|l|l|l|l|}
\hline Search for tasks & It's important to make & Keep talking to the & Posters will look at \\
nearby that match & sure your offer is at a & Poster regularly so & your profile and \\
your skill set by using & fair price, taking into & that they know what's & reviews so you've got \\
filtering for location, & account how long it & happening. When it's & to make a good first \\
distance, completing & could take and what & done, make sure you & impression! Upload a \\
in-person vs. & skills are needed. This & request for the & photo, write a nice \\
remotely, and by & could well be higher & payment to be & description, and list \\
searching keywords. & or lower than the task & released and leave an & the skills you're great \\
When you find the & price. Just make sure & honest and true & at. An awesome \\
right task, make an & you let the Poster & review for the Poster. & profile instantly \\
offer! & know why in your & improves your \\
offer. & & &
\end{tabular}

The literacy-intensive nature of the activities involved in negotiating a gig are illustrated in Figure 1 and Table 3, as is their social, relational character. As the instructions for "Browse tasks" make clear, the process of starting work ("starting to earn") for the gig worker begins with reading post texts produced by the customer, or "Poster" as Airtasker identifies them. It is also clear that the worker's production of an offer text (on other sites labelled a bid text) should be in direct response to their reading of a specific post text, articulating the time and skill requirements of the posted task in order to justify the offer. The dialogical nature of this negotiation centres on these two core texts of the post and the offer. It also extends beyond it. Indeed, "doing the task well" involves regular communication on the part of the worker to keep the customer/poster informed "so that they know what's happening". The importance of maintaining an "awesome" profile and attracting positive reviews as highlighted in Figure 1 further underscores the relationship-oriented character of working literacies in the gig economy. As we have discussed elsewhere, it is this focus on the building, maintenance and repair of working identities and working relationships that characterises the literate practice of work in Industry 4.0, of which the gig economy is part (Farrell, Newman \& Corbel, 2020).

While our focus is on the literacy demands placed on workers by online labour platforms like Airtasker, some examination of the literacy demands expected of the customer enables deeper 
understanding of this social, interactional nature of the literacy event that is the negotiation of gig work. These can be seen in Figure 2 and Table 4, another page from the Airtasker website that explains to potential customers "How it works" highlighting in bold the four main actions and text types of the gig work literacy event.

Figure 2

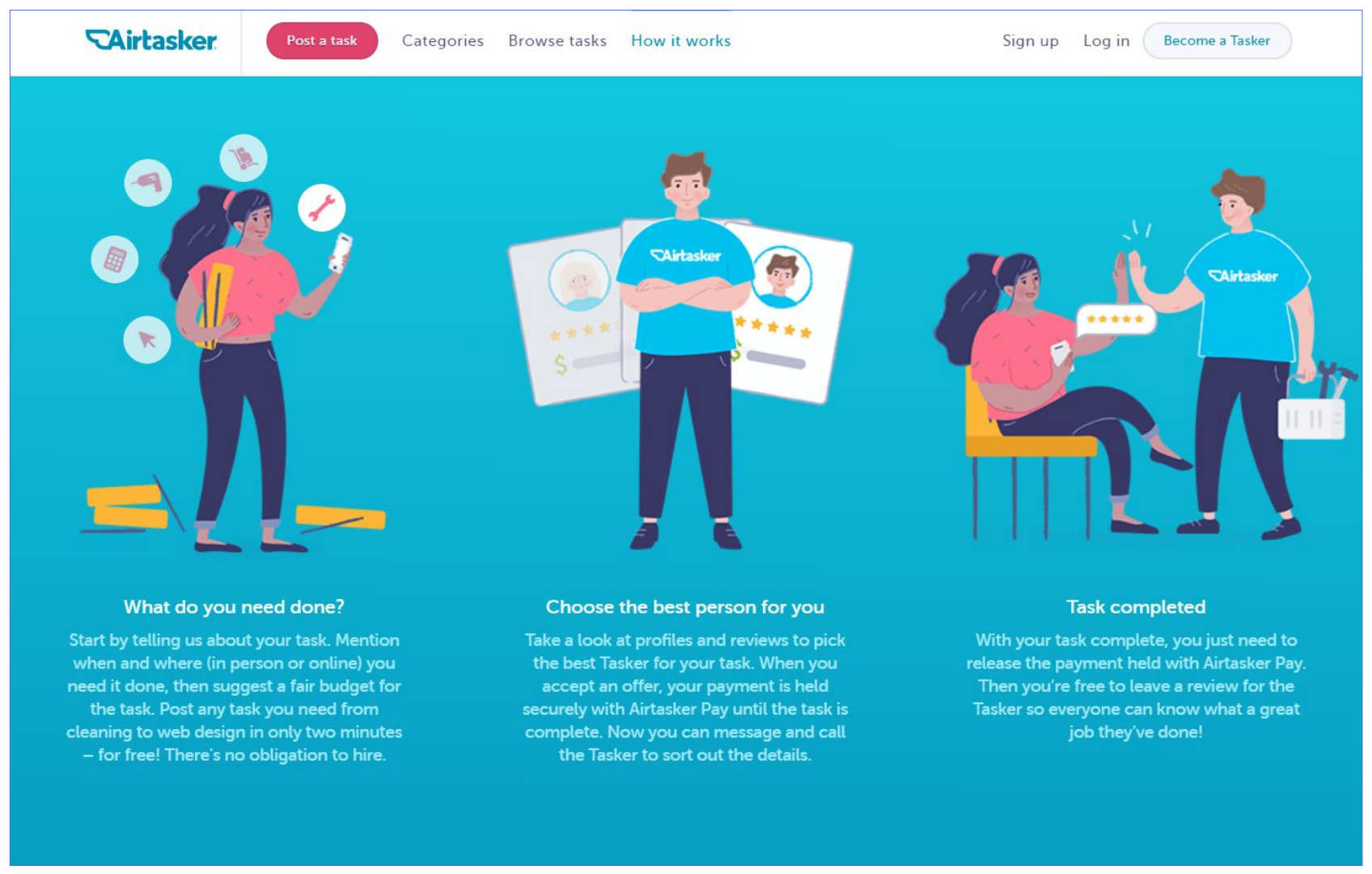

Table 4

Customer actions and text types in a gig work literacy event

\begin{tabular}{|l|l|l|}
\hline \multicolumn{2}{|c|}{ How it works } \\
\hline \multicolumn{1}{|c|}{ What do you need done? } & $\begin{array}{l}\text { Choose the best person for } \\
\text { you }\end{array}$ & \multicolumn{1}{|c|}{ Task completed } \\
\hline $\begin{array}{l}\text { Start by telling us about your } \\
\text { task. Mention when and }\end{array}$ & $\begin{array}{l}\text { Take a look at profiles and } \\
\text { reviews to pick the best Tasker } \\
\text { where (in person or online) } \\
\text { for your task. When you } \\
\text { you need it done, then suggest } \\
\text { a fair budget for the task. Post } \\
\text { any task you need from }\end{array}$ & $\begin{array}{l}\text { With your task complete, you } \\
\text { just need to release the } \\
\text { is held securely with Airtasker }\end{array}$ \\
cleaning to web design in only & Pay until the task is complete. & $\begin{array}{l}\text { Nay. Then you're free to leave } \\
\text { a review for the Tasker so } \\
\text { everyone can know what a } \\
\text { great job they've done! }\end{array}$ \\
\hline
\end{tabular}


two minutes - for free! There's $\quad$ the Tasker to sort out the no obligation to hire. details.

Airtasker's description of the literate practices required of the gig participants is typical of all sites reviewed in our study. All the platforms articulate a continuous cycle of posting and bidding for tasks and the platform architecture itself is geared towards providing for this social exchange, the core gig work literacy event. Notwithstanding the range of tasks to be done, there are strong similarities across all seven platforms in the types of texts involved in this process. The terminology changes only slightly: Freelancer, for example, calls an offer a bid, which is the term we have used in this article to capture the competitive element of the action. Overall, the terms post, bid, profile and review (as nouns and verbs) are the most frequent names for these actions and their associated texts.

In summary, the literacy event of negotiating a gig in the gig economy centres on two core writing activities, posting a task and bidding for a task. This post/bid interactive cycle is the fundamental social exchange that is facilitated by these online labour platforms that provide the digital architecture of the gig economy. The post/bid exchange is facilitated by two additional, optional activities: creating and maintaining a profile (by the worker) and posting a review (by the customer and/or the worker). The actual text types within a gig work literacy event were identified by expressing each of the actions in the event as a noun instead of a verb, giving us the text types of Post, Bid, Profile and Review. Gig work literacy events also involve giving and getting supporting texts providing Information and Instructions, and in some cases producing textual Products of varying complexity (see Table 1). Importantly, all of these actions and options are textually mediated, demanding literate social engagement.

These six text types were categorised according to their usage in the literacy event. Posts and Bids are required as an essential part of the gig negotiation process. Profiles and Reviews are advisable for the success of the gig completion process. Information and Instructions are optional 
and are available for use at any stage of the process if necessary. The texts which are created are the outcome or product of the gig work itself. This categorisation of gig work literacy event text types is summarised in Table 5.

Table 5

Gig work literacy event actions and texts

\begin{tabular}{|c|c|c|c|c|}
\hline $\begin{array}{c}\text { Text category } \\
\text { Usage }\end{array}$ & Process 1 & Process 2 & Support & Product \\
& Required & Recommended & Optional & Task-dependent \\
\hline Text type (n) & Post & Profile & (Give/Get) Instructions & \multirow{2}{*}{ Various } \\
\cline { 2 - 4 }$=$ Action (v) & Bid & Review & (Give/Get) Information & \\
\hline
\end{tabular}

Texts are broadly categorised as Process (1 and 2), Support or Product to emphasise the nature of their role and purpose in the event. Process texts directly shape the nature of the work to be done and the social contract of doing it. Two of these Process text types, Posts and Bids, are core to the literacy event itself. The other two Process text types, Profiles and Reviews, are recommended by the platforms to ensure success in bidding (McDonald et al., 2000). At each stage of the gig cycle two types of Support texts, Informational and Instructional, are available to provide assistance and to regulate communicative behaviour and social interaction on the platforms. Finally, some gigs require the preparation of a text as the output of the task, which we refer to as Product texts, though these are not part of every gig work literacy event. Process and Support texts are the foundational text categories in our model of the gig work literacy event, whatever the product or outcome may be. Crucially, the model shows that some form of engagement with written texts is required in all gig work, whether or not a task actually requires the production of a written text as a product.

We now turn to an examination of each of these text types in more detail. Process texts comprise Posts and Bids (Process 1) and Profiles and Reviews (Process 2), of which Posts and Bids are core to a gig work literacy event. Posts can be a few words (Airtasker, Freelancer) or quite lengthy 
(CrowdFlower/Appen). Some involve templates provided by the platform (CrowdFlower/Appen,

Scripted). Workers browse lists of tasks and select tasks to bid for. Tasks may be displayed to potential workers according to each worker's status on the platform (McDonald et al., 2020). Several platforms allow the customer to present the job as either a project or a contest. The use of competitive contests as well as collaborative projects introduces a "gamification" element (Fuchs et al., 2014) that blends other genres of online activity into a mixture of work and play, but also complicates relationships within the espoused community. The Bid is a written text which requires workers to distinguish themselves from the many other bidders. Other bids may be displayed to potential bidders and workers may be allowed to interact with customers to clarify the task (see Figures 1 and 2 and Tables 3 and 4). The result of this interaction is a jointly constructed text that takes the form of a chat, which have features of spoken and written language. They can occur in real time, though lags between responses are common, and may contain spelling or grammar errors. Some bidders emphasise their language ability as a point of difference, particularly when the task involves producing a written product text (Scripted). Most platforms provide advice on successful bidding in their Support texts.

Although a basic Profile is a requirement for becoming a member of the platform community as a worker, Profile updates and Reviews are merely recommended. Profiles range from a few words to detailed documents including samples of work and can be readily accessed by visitors and customers as well as other workers. Workers are encouraged to continually modify their Profiles, just as they would in other areas of social media. In so doing they develop both their working identities and their potential continuing relationships with customers. Profiles can be enhanced by contributing to the community in the form of feedback and responses to blogs and articles (Information texts). As in computer game play, moving up levels helps to evolve and promote a worker's profile. Levelling up can be achieved through improving metrics on job completion, or by undertaking internal training courses, for which the worker may have to pay (Freelancer). Reviews are optional, but customers and workers are encouraged to review each other 
and give feedback. Giving and receiving feedback is seen as a way to build profiles and trust within the community. Since feedback can have an effect on identity and status, some platforms provide guidance on how to provide it in the Support texts.

Support texts, unlike Process texts, are not integral to the gig work literacy event but provide a framework of support for the participants. These texts are mainly Informational but can also be Instructional. Included in these are the on-boarding texts required for new members (customers and workers) to join the community. Other resources include a range of texts which support, frame and develop the work of the community. Informational texts tend to focus on communication and news, serving to instantiate the community as they reflect back to the community the identity of the platform and what it means to be a member. They include guides, press releases, press reports, position descriptions and articles. All platforms provide written guides concerning how to get the best out of membership. These are usually written by team members and may also by be supplemented by workers in blogs, or by multimodal texts distributed via social media (e.g. Airtasker's YouTube channel). Freelancer, for example, provides explanations of how the site works provided by both team members and workers, suggesting that in some cases workers should seek guidance from the crowd (other workers) rather than the elite (team members). Blogs may be managed by team members or expert members of the community. They cover technical and social elements likely to be of interest to the community. Some are for members only while others are accessible to any visitor to the platform. Most have opportunities for posting comments. Externally authored texts may also be provided. CrowdFlower/Appen, for example, provides a link to an academic paper that shows how the services of the platform work for customers.

Instructional texts include documents, FAQs, and templates. All platforms have a document or section called something like How it works (See Figure 2/Table 3), which sets out the basics of the gig process. Instructions are usually written by team members, though some worker contributions to blogs also serve this function. This is an example of what was previously the work of professional 
technical writers (Barrett, 1993) becoming shared with non-specialists. Guides of various types, other than in relation to the Process texts, are written by team members and workers. These are often in the form of FAQs and other relatively unstructured texts, rather than in the form of a hierarchically structured text such as those traditionally associated with hardware and software support. Some form of structure may be provided in the form of templates to assist customers and workers to complete the Process texts.

A social view of literacy in the gig economy reveals the importance of both Process and Support texts in negotiating, maintaining and reproducing working relationships, identities and knowledge among participants in a platform community. While Process texts are essential for negotiating and completing the work itself, Support texts are necessary for the establishment of norms of participation within a platform community and, indeed, of the identity of the community itself. Worker engagement in the production of both kinds of texts is particularly apparent in relation to the negotiation of norms for chats which occur between customers and workers during the bidding process, usually to clarify a task. As the excerpt from an Airtasker "Community Summit Q\&A Session" below illustrates, workers may provide feedback to team members on the platform's efficacy in supporting the creation of Post and Bid texts. In this example, workers express the need for "more accurate task descriptions" from customers, leading to a change in the platform's communication infrastructure towards more efficient negotiation of the gig. In other words, customers are required to conform their Post texts to new literacy standards as a direct result of workers' contribution to this Support text.

\section{What is Airtasker doing to make sure that Job Posters provide a more accurate task description, instead of basic "move furniture"? \\ We'll be building more customised task templates that make it easier and clearer to Job Posters the type of information that needs to be included. (Airtasker 2017)}


Because chats lack the visual feedback that face-to-face communication provides, jointly creating such texts in real time is a complex task, particularly since the relationships between community members may not be well-developed. The platform's response to "build more customised task templates" is a direct result of worker participation in the production of the Support text that is the Airtasker Community Summit Q\&A Session (Airtasker 2017).

Product texts are those which are the typical outcomes of tasks, rather than being part of the gig work literacy event itself like Process and Support texts. As discussed above, the extent to which texts are outcomes of a task rather than part of the gig work process varies across the platforms, broadly according to how generalised or specialised their services are. Generalist platforms like Airtasker and Freelancer offer text preparation as one of a wide range of task offerings. These platforms may not highly concerned with all aspects of these texts since they are relatively well-framed by the task, as in editing for example. However, there are also requests for texts such as essays to be written, which is a matter of concern for educators concerned with cheating on assessments. The number and nature of Product texts vary greatly between platforms, from very low (Airtasker) to very high (Scripted). They range from blog entries to complex written reports and multimedia teaching materials. Although all platforms require a basic level of facility with written language for navigation of the platform and negotiation of the gig, the seven platforms vary in complexity broadly in line with the complexity of the product texts and worker specialisation required. Specialist platforms exert higher levels of control, whether in the forms of restrictions on entry (Scripted), or highly visible outputs (99designs and Skillshare). Each of the three specialist writing platforms focuses on a particular textual mode, from alphabetic texts (Scripted) through graphic texts (99designs) to multimedia texts (Skillshare). Consistent across all of the platforms are the more hidden minimum literacy demands involved in negotiating the gig, which, as we have shown, may involve some rather sophisticated and socially intensive communication practices. 
Our examination of the literacy practices of the gig economy has revealed three categories of text, Process, Support and Product, as summarised in Table 5 above. At the centre of gig work are the Process texts. The Process 1 Texts, the Post and the Bid, are required for participation in gig work. The Process 2 texts, the Profile and Review, are recommended for success in gig work. Process 2 texts are recognisable general text types that occur in other contexts as well. However, the Process 1 texts are harder to identify as existing text types, although they do display some features of digital chats. One reason for the difficulty in identification of the Process 1 texts is that given the nature of the data collection there were fewer of these texts accessible to a visitor or inactive worker than Process 2 or Support texts. The actual exchanges that comprise the Posting and Bidding are mostly hidden to non-participants. Nevertheless, the Process 1 texts examined appear to have features of what Miller (2017) calls "vernacular genres", found "...in situations where users have few institutional and administrative constraints and collectively create a way of addressing a shared exigence" (p. 24). These exigences "are not always obvious and available for inspection; they may 
have to be inferred by the researcher..." (ibid p. 24). Such inferences underlie the model presented here, which identifies the Post and Bid (Process 1) texts as core to the gig work literacy event.

Always available to users of the Process texts are the Support texts, primarily Informational and Instructional. Their usage is optional. They provide support for various aspects of gig work, as well as helping to establish the norms of behaviour required for participation in a platform community. They accompany the Process texts, reflecting what Askehave and Nielsen (2005) call "web-mediation", the role of the medium in the analysis of digital texts. Askehave and Nielsen identify a process of "zoom in, zoom out" with digital texts, which captures the nature of the nonlinear, or circular, engagement with the Process and the Support texts in gig work, whereby participants are able to access additional information or support during an event by following links out to the Support texts and back into the Process texts.

Unlike the Process texts, all the Support and Product texts examined were of a recognisable general text type, as frequently captured in their titles (See Appendix). Some of these, such as position description, are well established. Others, such as blog entry, are newer, but nevertheless widely used (de Pourbaix, 1999). Support texts (both Informational and Instructional) are typical of what Miller (2017) calls "administered genres", which circulate in institutional settings where those with power can influence processes. As we have shown, however, both team members and workers can contribute texts to these categories, thus sharing (or at least dialogically negotiating) the power and control to some extent. Product texts are the outcomes of many of the gig work tasks undertaken. Many texts involve a mix of both screen and print-based media as part of their development and presentation (Martin \& Lambert, 2015). They utilise features of different semiotic systems and different media. Product texts are typical of what Miller (2017) calls "commercial genres", where there is a "strong distinction between producer and consumer" (ibid p. 23).

Do the central processes of gig work, the Posting, Bidding, Profiling and Reviewing, comprise a distinctive gig work genre? As Bawarshi and Reiff (2010) point out, "Following John Swales, ESP 
... genres emerge not only from technological change and media transformation but also from marketing and commercial constraints, the conditions of production, antecedent genres, sociocultural and psychosocial change, influential individuals and their goals and commitments, critical appraisal and deliberate recombination, play and experimentation, and institutional and political change. (Miller, 2017, p. 26)

We suggest that the Process texts (Bid, Post, Profile and Review) may usefully be considered as an emergent vernacular genre. This also requires further investigation, particularly in relation to the constraints as well as the opportunities offered by the platforms themselves for managing shared exigences, for instance, whether Airtasker really did implement new task design templates and whether these new templates improved communication between the customer and the worker about the nature of the task.

A fuller understanding of the requirements of a gig work literacy event clearly requires an understanding of the social practices surrounding it. Our analysis suggests that these established and emerging text types have common features across platforms. Our argument is that these features both enable and constrain the negotiation and reproduction of working identities, working relationships and working knowledge on which the gig economy relies. We have shown that there is 
an inherent tension within these platforms between the avowed cooperation and the underlying competition between workers, and between workers and team members. There have been increasing cases of workers going outside the platforms to seek legal clarification for their work status (de Ruyter et al, 2018). Building a reputation and maintaining trust are at the heart of online labour markets (Nica, Potcovaru \& Mirica, 2017). It is therefore not surprising that the development and maintenance of workplace relationships, identity and knowledge underlies every aspect of the core literacy event in gig work. Although optional, active engagement in the Process 2 texts (Profiles and Reviews) contributes to building relationships and identity with other community members. Active engagement as reader and writer with the Support texts, both Instructional and Informational, builds community members' personal and shared knowledge bases. As we have emphasised throughout this article, online labor platforms are workspaces, not workplaces for the vast majority of participants. The capacity for face-to-face engagement and traditional forms of linguistic repair were therefore limited even before the COVID pandemic, so the literacy requirements of co-creating digital textual engagement are now magnified as more people work online and at a distance from each other. The convergence of spoken and written language and numeric and visual systems into complex real-time texts leads not just to the need for more of the established language, literacy, numeracy and digital skills, but for a greater capacity to do this textual and social work at a distance, mediated via a screen as well as by a particular app and platform infrastructure. The ways that these apps and platforms are designed and structured have direct bearing on how the social activities of textual production and engagement play out in contemporary times.

\section{Implications}

This article has examined the literacy event at the heart of work in the gig economy, and its associated practices and texts, as they are manifested in the workings of seven online labor gig 
platforms. It has presented these in the form of a model of text types and categories. This is intended as a starting point, a heuristic to facilitate further critical investigation. We conclude with a consideration of the potential implications of this model of literacy practice for pedagogy, curriculum and for learning in the workspace domain itself.

Pedagogically the notion of the gig as a form of employment provides a potential framing for topic-based school, vocational and professional teaching. Selecting and sequencing content for teaching could begin with Process texts and move on to Support and Product texts, providing a principled means of staging learning. A gig work literacy event can provide a framework for taskbased activity. The identification of gig roles can facilitate role play and group work. Profile writing is practice for resume writing (and may have already replaced it). Reviewing provides practice in interpersonal skills such as giving and receiving feedback with colleagues. Activities can be differentiated according to gig roles and learners' preferred forms of engagement, such as those identified according to their level of participation as "passengers", "navigators" and "drivers" (Martin \& Lambert, 2015). These activities, in turn, can be extended into more critical discussion of the social nature of gig work, as well as of the affordances and limitations of different platforms in support of this social event. Finally, writing activities can focus on different mixes of paper-based and screen-based writing, with the screen used as both a step towards producing a paper-based text, and also for screen-based writing as an end product in itself.

At the simplest level, existing curriculum frameworks can benefit from an enhanced range of examples for teaching existing text types, both textual and rhetorical. Course development for accreditation and reaccreditation can draw upon the broad domains of literacy practices that frame gig work literacy events and their associated texts. National and international assessment frameworks can be guided in the same way. As well as focusing on writing skills, educators can develop students' knowledge of the gig economy in greater depth, addressing issues such as the 
precariousness of gig employment, the relative scarcity of secure jobs, and the power relationships within the platforms themselves.

Beyond formal educational settings the focus in professional writing instruction has traditionally been on what we have called Product texts, the outcomes of gig work, often done within an organisational setting. While competency in the relevant genres of these texts remains as important as ever, a critical understanding of how these texts are framed within gig work literacy events, and competency in the management of Process as well as Product texts, will be of increasing importance in all areas of work in this era of massification of writing. At the same time, the kind of assistance once provided by Support texts generated within organisations and workplaces is increasingly the responsibility of the platform workers themselves, as well as the platform team members.

Addressing the perceived "literacy crisis" (Black \& Yasukawa, 2011) in Industry 4.0 requires literacy educators to think more broadly about what Literacy 4.0 might involve. Literacy 4.0 needs to be seen not just as readily transferrable, individual skills but as context-specific social competencies and knowledge needed for effective and critical engagement in domains of activity such as the gig economy. As a step towards addressing this need, we have presented a model of the literacy event that characterises gig work and an analysis of the texts and literacy practices involved. We propose an informed and critical engagement (what Pennycook (1997) calls "critical pragmatism") with the literacy practices, events and texts required for participation in the gig economy and in the communities of practice that emerge from different platforms, a more critical form of "gig literacy" than envisaged by Sutherland et al. (2020). This should be central to the development of pedagogy, curriculum and policy for work-related literacy education in the current era. Further research that engages directly with gig economy participants will help to deepen our understanding of the literacy practices required for online labor platform work as it becomes increasingly common and as the business model inevitably transforms (Srnicek, 2017). 
This research also bears wider implications in terms of the literacies needed for work generally in the current era, as digital platforms are increasingly being used across multiple industries and multiple types of work, as well as different kinds of work roles, to get work done. Within as well as between companies and organisations, digital platforms are being used extensively to enable teamwork and collaboration among workers, to hold meetings, to problem solve and make decisions, as well as to chat and interact socially in and around work activities - that is, to build, maintain and repair working relationships. In short, digital platforms are increasingly being used to provide the infrastructure for working literacy in contemporary times (Frith, 2020). As our discussion here of the literacy demands of gig economy platforms highlights, platforms can define the constraints as well as the possibilities for communication between users performing different roles. Indeed, by their design they define the available roles as well as the text types through which humans may interact and thus can determine what it is to be a worker. It is only through a critical understanding of literacy as a social practice that we will be able to adequately attend to the education and training needs of human workers and resist their commodification and exploitation in a world where online behaviour is so readily and rapidly converted to data, which in turn become texts to be collected, analysed and interpreted.

There is now added urgency. In a pandemic-induced lockdown, and in the post-lockdown world, it is not just gig workers but potentially all workers who will have to face the reality of geographically dispersed, digitally mediated workspaces replacing physically bounded workplaces. Understanding the nature of the texts and textual practices that constitute and define work in these spaces is likely to become an increasingly central concern of work-related literacy education and workforce development in the times ahead.

\section{Appendix}

\section{Platform texts}




\begin{tabular}{|c|c|c|c|}
\hline $\begin{array}{l}\text { Text } \\
\text { Source }\end{array}$ & Text title & Text type common name & $\begin{array}{l}\text { Gig text category/ } \\
\text { Gig text type }\end{array}$ \\
\hline AT1 & The future of work: Airtasker research & Blog entry & Support/Informational \\
\hline AT2 & Customer Experience Specialist & Position Description & Support/Informational \\
\hline AT3 & Product Designer & Position Description & Support/Informational \\
\hline AT4 & Job (gig) Description/Offers & Position Description & Process 1/ Post and Bid \\
\hline CF1 & CrowdFlower Potential Jobs & Position Description & Process 1/ Post \\
\hline CF2 & Hillier et al. (2016) (details below) & Academic journal article & Support/Informational \\
\hline CF3 & S1 Text CrowdFlower job instructions & Task instructions & Process1 /Post \\
\hline CF4 & $\begin{array}{l}\text { Using Crowd Flower to understand } \\
\text { storytelling in science }\end{array}$ & Blog entry & Support/Informational \\
\hline FL1 & Research writers in Australia for hire & Resume & Process 2/Profile \\
\hline FL2 & Research writing jobs & Advertisement & Process 1 /Post \\
\hline FL3 & Research paper & Advertisement & Process1/Bid \\
\hline FL4 & 10 tips for writing an effective bid & Guide & Support/ Instructional \\
\hline FL5 & How to rate an employer & Guide & Support/ Instructional \\
\hline FL6 & How does Freelancer.com work? & Blog entry & Support/Informational \\
\hline LM1 & Local Motors introduces Forth & Media release & Support/Informational \\
\hline LM2 & Junior Producer - Boulder Location & Position Description & Support/Informational \\
\hline LM3 & Employee Spotlight & Blog entry & Support/Informational \\
\hline ND1 & Senior copywriter & Position Description & Support/Informational \\
\hline SC1 & We're hiring & Position Description & Support/Informational \\
\hline SC2 & Whitepaper & Task description & Support/Informational \\
\hline SC3 & Proficiency test & Quiz & Support/Instructional \\
\hline SC4 & Getting what you pay for & Blog entry & Support/Informational \\
\hline SK1 & Teaching FAQs & FAQ & Support/Informational \\
\hline SK2 & $\begin{array}{l}\text { Skillshare: Redesigning education for the } \\
\text { masses }\end{array}$ & Media report & Support/Informational \\
\hline SK3 & $\begin{array}{l}\text { Skillshare raised } 3.1 \mathrm{~m} \text { to turn everyone } \\
\text { into teachers }\end{array}$ & Media report & Support/Informational \\
\hline SK4 & Associate Community Manager & Application form & Support/Informational \\
\hline SK5 & Associate Community Manager & Position Description & Support/Informational \\
\hline SK6 & Introducing portfolio reviews & Blog entry & Support/Informational \\
\hline
\end{tabular}

Hillier et al., (2016) Narrative style influences citation frequency in climate change science PLoS ONE 11(12)

\section{Acknowledgments}

We are grateful for the detailed feedback from three anonymous reviewers.

\section{References}

Airtasker. (2017). Airtasker Community Summit: Q\&A Session [Session notes]. Airtasker Blog. https://www.airtasker.com/blog/airtasker-community-summit-qa-session-notes/ 
Aloisi, A. (2016). Commoditized workers: Case study research on labour law issues arising from a set of "on demand/gig economy" platforms. Comparative Labor Law \& Policy Journal, 37(3), 653-690.

Askehave, I., \& Nielsen, A. E. (2005). Digital genres: A challenge to traditional genre theory. Information Technology \& People, 18(2), 120-141.

Australian Industry Group (AIG) (2016). Emergence of the gig economy: AIG Group Workforce Development. https://cdn.aigroup.com.au/Reports/2016/Gig_Economy_August_2016.pdf Avis, J. (2018). Socio-technical imaginary of the fourth industrial revolution and its implications for vocational education and training: a literature review. Journal of Vocational Education and Training, 70(3), 337-363.

Barrett, E. (Ed.) (1993). The society of text: Hypertext, hypermedia and the social construction of information. Cambridge, Mass: The MIT Press.

Barton, D. (1994). Literacy studies: An introduction to the ecology of written languages. Oxford: Blackwell Publishers.

Barton, D., \& Hamilton, M. (1999). Literacy practices. In D. Barton, M. Hamilton, \& R. Ivanic (Eds.), Situated literacies: Theorising reading and writing in context. London: Routledge.

Barton, D., Hamilton, M., \& Ivanič, R. (1999). Situated literacies : reading and writing in context. London: Routledge.

Bawarshi, A. S., \& Reiff, M. J. (2010). Genre: An introduction to history, theory, research, and pedagogy. West Lafayette, Indiana: Parlor Press.

Baynham, M. (1995). Literacy practices: Investigating literacy in social contexts. London: Longman. Baynham, M., \& Prinsloo, M. (2009). The future of Literacy Studies. Basingstoke: Palgrave Macmillan. Black, S., \& Yasukawa, K. (2011). A tale of two councils: Alternative discourses on the 'literacy crisis' in Australian workplaces. International Journal of Training Research, 9(3), 218-233.

Brandt, D. (2005). Writing for a living: Literacy and the knowledge economy. Written Communication, 22(2), 166-197. 
Brandt, D. (2009). Writing after reading. In M. Baynham \& M. Prinsloo (Eds.), The future of Literacy Studies. Basingstoke: Palgrave Macmillan.

Brandt, D. (2015). The rise of writing: Redefining mass literacy. Cambridge: Cambridge University Press.

Brown, J. S., \& Duguid, P. (2000). The social life of information. Boston, Mass: Harvard Business School Press.

Carrigan, M. (2018). What is platform literacy? https://markcarrigan.net/2018/05/13/what-isplatform-literacy/

Chalmers, J., \& Quigley, M. (2017). Changing jobs: The fair go in the new machine age. Melbourne: Black Inc.

Coldwell-Neilson, J., \& Cooper, T. (2019). Digital literacy meets industry 4.0 (Vol. 2), 37-50. Leiden: Koninklijke Brill NV.

Collin, R. (2011). Selling the self: career portfolios and the new common-sense of immaterial capitalism. Social Semiotics, 21(5), 615-632.

Cope, B., \& Kalantzis, M. (Eds.). (2000). Multiliteracies: Literacy learning and the design of social futures. London: Routledge.

de Pourbaix, R. (1999). Emergent literacy practices in an electronic community. In D. Barton, M. Hamilton, \& R. Ivanic (Eds.). Framing languages and literacies: Socially situated views and perspectives: London: Routledge.

de Ruyter, A., Brown, M., \& Burgess, J. (2018). Gig work and the fourth industrial revolution; Conceptual and regulatory challenges. Journal of International Affairs, 72(1), 37-50.

Dean, M., \& Spoehr, J. (2018). The fourth industrial revolution and the future of manufacturing work in Australia: challenges and opportunities. Labour \& Industry: A journal of the social and economic relations of work. 21(3), 166-181.

Deloitte Development LLC. (2017). Rewriting the rules for the digital age - The future of work: The augmented workforce. 
https://www2.deloitte.com/content/dam/Deloitte/us/Documents/human-capital/hc-2017global-human-capital-trends-us.pdf

Ducheneaut, N., \& Bellotti, V. O. (2001). E-mail as habitat: An exploration of embedded personal information management. Interactions, 8(5), 30-38.

Farrell, L. (2000). Ways of doing, ways of being: Language, education and 'working' identities. Language and Education, 14(1), 18-36.

Farrell, L. (2001). The 'new word order': Workplace education and the textual practice of economic globalization. Pedagogy, Culture and Society, 9(1), 57-75.

Farrell, L. (2006). Making knowledge common: Literacy and knowledge at work. New York: Peter Lang.

Farrell, L. (2009). Texting the future: Work, literacies and economies. In M. Baynham \& M. Prinsloo (Eds.), The Future of Literacy Studies (181-198). New York: Palgrave Macmillan.

Farrell, L., \& Fenwick, T. (Eds.). (2007). Educating the global workforce: Knowledge, knowledge work and knowledge workers. Abingdon: Routledge.

Farrell, L., Newman, T., \& Corbel, C. (2020). Literacy and the workplace revolution: a social view of literate work practices in Industry 4.0. Discourse: Studies in the Cultural Politics of Education, $1-15$.

Fehring, H. (2020). There is more to education than the demands of the Industrial Revolution 4.0: A focus on literacy expectations. Advances in Social Sciences Research Journal, 7(2), 100-108.

Fisher, L. (Ed.) (2016). Best practice for knowledge workers: Innovation in Adaptive Case Management. Lighthouse Pt , FLA: Future Strategies Inc.

Frith, J. (2020). Technical standards and a theory of writing as infrastructure. Written Communication, 37(3), 401-427.

Fuchs, M., Fizek, S., Ruffino, P., \& Schrape, N. (2014). Rethinking gamification: Meson Press, University of Lüneburg, Germany. 
Garcia, A. C., Standlee, A. I., Bechkoff, J., \& Cui, Y. (2009). Ethnographic approaches to the internet and computer-mediated communication. Journal of Contemporary Ethnography, 38(1), 52 84.

Gee, J. P., Lankshear, C., \& Hull, G. (1996). The New Work Order: Behind the language of the New Capitalism. St. Leonards, N.S.W: Allen \& Unwin.

Gegenhuber, T., \& Schlussler, E. (2020). Microphones, not megaphones: Functional crowdworkers' voice regimes on digital work platforms. Human Relations, 1-31 first online.

Graddol, D., Maybin, J., \& Stierer, B. (Eds.). (1994). Researching language and literacy in social context. Clevedon: Multilingual Matters Ltd.

Hamilton, M., Barton, D., \& Ivanic, R. (Eds.). (1994). Worlds of literacy. Clevedon, Avon: Multilingual Matters.

Hawkins, M. R. (2013). Framing languages and literacies: Socially situated views and perspectives. New York: Routledge.

Healy, J., Nicholson, D., \& Pekarek, A. (2017). Should we take the gig economy seriously? Labour \& Industry: a journal of the social and economic relations of work, 27(3), 232-248.

Hull, G., \& Zacher, J. (2007). Identity formation and literacy development within vocational education and work. In L. Farrell \& T. Fenwick (Eds.) (2007).

Jaworski, A. (2015). Globalese: a new visual-linguistic register. Social Semiotics, 25(2), 217-235.

Karlsson, A.-M., \& Nikolaidou, Z. (2016). The textualization of problem handling: Lean discourses meet professional competence in eldercare and the manufacturing industry. Written Communication. 33(3), 275-301.

King, N. (2012). Doing template analysis. In C. Cassell \& G. Symon (Eds.), Qualitative organizational research: Core methods and current challenges (pp. 426-450). London: Sage.

Kirschenbaum, M. G. (2016). Track changes: A literary history of word processing. Cambridge, Mass: The Belknap Press of Harvard University Press. 
Kozinets, R. (2010). Netnography: Doing ethnographic research online. Thousand Oaks, CA: Sage Publications.

Martin, C. J. (2016). The sharing economy: A pathway to sustainability or a nightmarish form of neoliberal capitalism? Ecological Economics, 121, 149-159.

Martin, N. M., \& Lambert, C. (2015). Differentiating digital writing Instruction: The intersection of technology, writing Instruction, and digital genre knowledge. Journal of Adolescent \& Adult Literacy, 59(2), 217-227.

McDonald, P., Williams, P., Stewart, A., Mayes, R., \& Oliver, D. (2019). Digital platform work in Australia: Prevalence, nature and impact. https://s3.ap-southeast2.amazonaws.com/hdp.au.prod.app.vicengage.files/6915/6081/7253/Digital_Platform_Work_in_Australia__Preliminary_Findings_18_June_2019.pdf

Messina-Dahlberg, G., \& Bagga-Gupta, S. (2016). Mapping language in digital spaces: Literacy practices at borderlands. Language Learning and Technology, 20(3), 80-106.

Miller, C. R. (1984). Genre as social action. Quarterly Journal of Speech, 70, 151-176.

Miller, C. R. (2015). Genre as Social Action (1984), Revisited 30 Years Later (2014). Letras \& Letras, 56-72. https//doi:10.14393/LL63-v31n3a2015-5

Miller, C. R. (2017). Where do genres come from? In C. R. Miller \& C. Kell (Eds.), Emerging genres in new media environments. Palgrave Macmillan.

Nica, E., Potcovaru, A.-M., \& Mirica, C.-O. D. (2017). A question of trust: cognitive capitalism, digital reputation economy, and online labor markets. Economics, Management, and Financial Markets, 12(3), 64-69.

Pennycook, A. (1997). Vulgar pragmatism, critical pragmatism, and EAP. English for Specific Purposes, 16(4), 253-269. 
Pigg, S., Grabill, J. T., Brunk-Chavez, B., Moore, J. L., Rosinski, P., \& Curra, P. G. (2014). Ubiquitous writing, technologies, and the social practice of literacies of coordination. Written Communication, 31(1), 91-117.

Richardson, L. (2015). Performing the shared economy. Geoforum, 67, 121-129.

Rolandsson, B., Saloniemi, A., \& Saari, T. (2020). High-skilled platform work in Finland and Sweden the case of technical translators. In K. Jesnes \& S. Oppegaard (Eds.), Platform work in the Nordic models: Issues, cases and responses (pp. 47-51): TemaNord 2020:513.

Schwab, K. (2016). The Fourth Industrial Revolution. Geneva: World Economic Forum.

Sellen, A. J., \& Harper, R. (2002). The myth of the paperless office. Cambridge, Mass. : MIT Press.

Sennett, R. (1998). The corrosion of character: the personal consequences of work in the new capitalism. New York: W.W. Norton \& Company.

Sindhwani, P., \& Ahuja, V. (2014). A study of online co-creation strategies of Starbucks using Netnography. International Journal of Online Marketing, 4(1).

Srnicek, N. (2017). The challenges of platform capitalism: Understanding the logic of a new business model. Juncture, 23(4), 254-257.

Standing, G. (2011). The Precariat. London: Bloomsbury Academic.

State of Victoria (2020). Report of the inquiry into the Victorian on-demand workforce. Melbourne: Victorian Government. http://engage.vic.gov.au/inquiry-on-demand-workforce.

Street, B. (1993). Introduction: The new literacy studies. In B. Street (Ed.), Cross-cultural approaches to literacy. Cambridge: Cambridge University Press.

Sutherland, W., Jarrahi, M. H., Dunn, M., \& Nelson, S. B. (2020). Work precarity and gig literacies in online freelancing. Work, Employment and Society, 34(3), 457-475.

Thorne, S. L. (2013). Digital literacies. In M. R. Hawkins (Ed.), Framing languages and literacies: Socially situated views and perspectives. New York: Routledge.

Turkle, S. (1997). Life on the screen: Identity in the age of the internet. London: Phoenix. 
Wisskirchen, G. (2017). Artificial Intelligence and Robotics and their impact on the workplace.

London: International Bar Association Global Employment Institute.

Zuboff, S. (1988). In the age of the smart machine. New York: Basic Books.

Zuboff, S. (2019). The age of surveillance capitalism: The fight for a human future at the new frontier of power. London: Profile Books Ltd.

\title{
Notes
}

\begin{abstract}
${ }^{1}$ For instance, speaking and listening may increasingly be involved as videos augment or even replace written texts in worker profiles and in instructional and informational texts. For instance, Airtasker's "How it works" page includes an informational video linked to the company's YouTube channel, which also features various workers or "taskers" who find regular work via the platform. See: https://www.youtube.com/watch?v=vRObPjevAUU.

2 "How to start earning" page from Airtasker (https://www.airtasker.com/earn-money/; accessed March 2021)

3 "How it works" page from Airtasker (https://www.airtasker.com/how-it-works/; accessed March 2021)
\end{abstract}




\section{University Library}

\section{- M M I N E R VA A gateway to Melbourne's research publications}

Minerva Access is the Institutional Repository of The University of Melbourne

Author/s:

Corbel, C;Newman, T;Farrell, L

Title:

Gig Expectations: Literacy Practices, Events, and Texts in the Gig Economy

Date:

2021-11-04

Citation:

Corbel, C., Newman, T. \& Farrell, L. (2021). Gig Expectations: Literacy Practices, Events, and Texts in the Gig Economy. WRITTEN COMMUNICATION, 39 (1), pp.66-96. https:// doi.org/10.1177/07410883211052941.

Persistent Link:

http://hdl.handle.net/11343/294179 